\title{
Architektura sakralna Opola w okresie dwudziestolecia międzywojennego
}

\author{
Elżbieta Przesmycka \\ e-mail: elzbieta.przesmycka@pwr.edu.pl \\ Wydziat Architektury, Politechnika Wroctawska
}

\section{Joanna Kania}

e-mail:joanna.kania@pwr.edu.pl

Wydziat Architektury, Politechnika Wroctawska

\section{Wojciech Jabłoński}

e-mail:wojciech.jablonski@pwr.edu.pl

Wydziat Architektury, Politechnika Wrocławska

\begin{abstract}
Streszczenie: Z powodu dynamicznego wzrostu ludności miasta niezbędne okazało się wybudowanie nowych osiedli mieszkaniowych i towarzyszących im obiektów użyteczności publicznej. Do XX wieku na terenie Opola znajdowało się jedynie pięć świątyń katolickich, które nie były w stanie pomieścić powiększającej się ilości wiernych. W związku z tym w okresie dwudziestolecia międzywojennego na terenie Opola wybudowano cztery kościoły. W poniższym artykule przedstawiono rozwiązania przestrzenne kościołów pw. św. Piotra i Pawła, pw. Najświętszego Serca Pana Jezusa, św. Józefa oraz św. Michała Archanioła.
\end{abstract}

Słowa kluczowe: Opole, kościoły, modernizm, dwudziestolecie międzywojenne

\section{Wstęp}

Po I wojnie światowej ranga administracyjna Opola zaczęła stopniowo wzrastać. W 1922 roku miasto zostaje siedzibą władz prowincji górnośląskiej. Był to jeden z wielu czynników, który spowodował gwałtowny napływ ludności, co z kolei przyczyniło się do szybkiego rozwoju tkanki miejskiej. Konieczne stało się wybudowanie nie tylko nowych osiedli mieszkaniowych, ale także towarzyszących im obiektów użyteczności publicznej, w tym również nowych obiektów sakralnych.

Przedstawione w tym artykule zagadnienie zostało jedynie szczątkowo opisane w literaturze. Ogólny opis obiektów architektury sakralnej sporządziła w swojej dysertacji doktorskiej „Wybrane aspekty rozwoju przestrzennego Opola w latach 1816-1945" Monika E. Adamska. O opolskich kościołach wzmiankował również Otto Spisla w pozycji pt. „Oppeln in den Stürmen der Zeit”, pomijając jednak kontekst architektoniczny.

Do XX wieku na ówczesnym terenie miasta znajdowało się pięć świątyń związanych z religią chrześcijańską. Najbardziej rozpoznawalną z nich była położona w historycznym centrum XV-wieczna kolegiata Podwyższenia Krzyża Świętego, która powstała na miejscu wcześniejszych kościołów z XI i XIII wieku. Obiekt ten był wielokrotnie przebudowywany i modyfikowany na przestrzeni wieków, co wynikało głównie ze zniszczeń spowodowanych częstymi pożarami, które nawiedzały miasto. Ostatnim remontem przed wybuchem II wojny światowej było dobudowanie wieżyczki schodowej do wieży północnej oraz rozbudowa chóru w latach 1912-1914 [1]. Oprócz kolegiaty, w obrębie murów miejskich położone były cztery kościoły - pochodzący z X wieku kościół św. Wojciecha (obecnie p.w. Matki Boskiej Bolesnej i św. Wojciecha), a także XIV-wieczny kościół św. Trójcy, XV-wieczny kościół św. Aleksego oraz XVII-wieczny kościół św. Sebastiana, będące kościołami filialnymi parafii Podwyższenia Krzyża Świętego. 


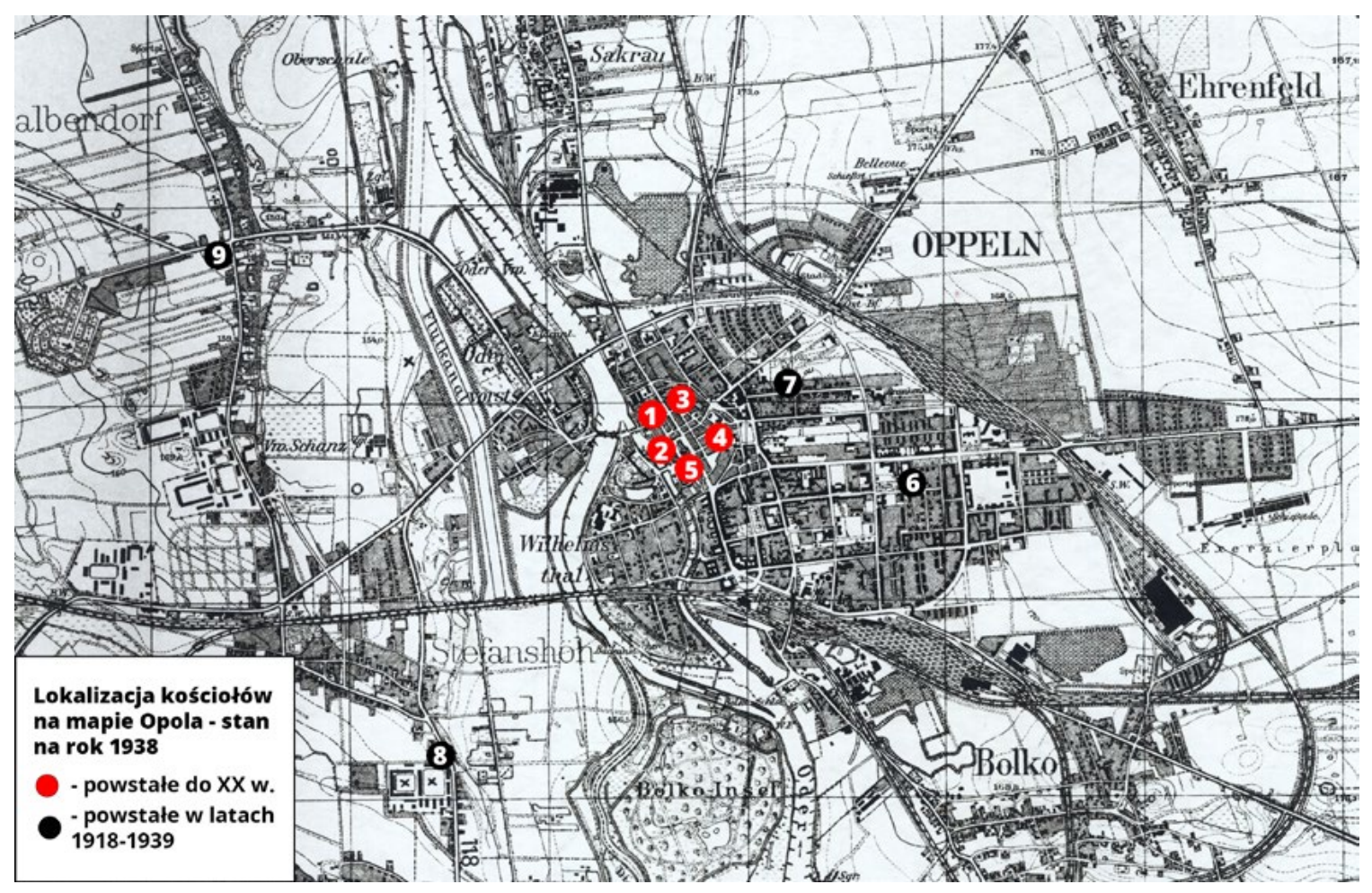

Ryc. 1. Lokalizacja kościołów na mapie Opola - stan na rok 1938. (Opracowanie własne na podstawie mapy z 1938 roku. Źródło mapy: http://mapywig.org).

1 - Kolegiata Podwyższenia Krzyża Świętego; 2 - Kościół św. Aleksego; 3 - Kościół św. Sebastiana; 4 - Kościół św. Wojciecha; 5 - Kościół św. Trójcy; 6 - Kościół św. Apostołów Piotra i Pawła; 7 - Kościół Najświętszego Serca Pana Jezusa; 8 - Kościół św. Józefa; 9 - Kościół św. Michała Archanioła

\section{Kościół św. Apostołów Piotra i Pawła - 1923-1924}

W związku z powstającą we wschodniej części miasta nową dzielnicą mieszkaniową, proboszczowie parafii Podwyższenia Krzyża Świętego na przełomie XIX i XX wieku rozpoczęli starania mające na celu wybudowanie nowego miejsca zgromadzeń. Po uzyskaniu przychylności władz rozpoczęto poszukiwania odpowiedniego miejsca na ulokowanie świątyni. Początkowo brano pod uwagę dwie lokalizacje: należącą do radnego miejskiego Baydla część posesji pomiędzy ulicami Krakauerstrasse (obecnie ul. Krakowska) i Sternstrasse (obecnie ul. Reymonta) oraz obszar znajdujący się na wschód od Friedrichsplatz (obecnie pl. Daszyńskiego). Wybrano drugi teren, jednak ostatecznie prac nie zapoczątkowano z powodu ciągłych zmian na stanowisku proboszcza i braku pozwolenia na rozpoczęcie budowy. W 1909 roku zmieniono lokalizację - miasto bezpłatnie przekazało nową działkę o wielkości $7487 \mathrm{~m} 2$ pomiędzy ulicami Vogtstrasse (obecnie ul. Katowicka) a Bluecherstrasse (obecnie ul. Miarki). W 1913 roku powstał projekt kościoła i towarzyszących mu zabudowań, którego autorem był architekt Welz z Berlina. Prace przygotowawcze przerwał wybuch I wojny światowej. Po zakończeniu wojny wznowiono starania o powstanie kościoła, jednak brakowało pieniędzy na jego wykonanie. Urzędującemu wtedy w parafii księdzu prałatowi Józefowi Kubisowi udało się się jednak otrzymać milion marek od rządu, za który zakupiono materiały budowlane. Ostatecznie większość kosztów związanych z budową przejęło na siebie państwo, uzyskując tym samym nadzór nad powstającą świątynią. Zrezygnowano z projektu architekta Welza, który zastąpiono nowym, wykonanym w dziale budownictwa Pruskiego Ministerstwa Finansów pod kierunkiem nadradcy budowlanego Arthura Kicktona. Nadzór nad budową sprawował natomiast radca rządu i budowy Arthur Reck. Bryła świątyni została ulokowana na częściowo sztucznym wzniesieniu, dzięki czemu możliwe było wykonanie schodów i tarasów przy obejściu. Pierwsze prace rozpoczęto 23 kwietnia 1923 roku. Betonowy kościół 
jest trójnawowym, orientowanym obiektem na planie krzyża łacińskiego, w układzie bazylikowym z transeptem i jedną wieżą ulokowaną po stronie zachodniej. Przed frontową fasadą znajduje się rozległy taras, do którego prowadzi 11 betonowych schodów. Kolejne pięć schodków prowadzi do kruchty z arkadami, w której ulokowano troje drzwi wejściowych. Po prawej stronie od kruchty znajduje się wieża, której czworoboczna podstawa przechodzi w ośmiobok na wysokości sklepienia nawy głównej. Wieża zdobiona jest figurami aniołów i gryfonów oraz zegarami. Przekryto ją kopulastym hełmem wykonanym z blachy miedzianej. Poza wieżą, pozostała część bryły pozbawiona jest zdobień, elewacja jest surowa, nieotynkowana, z widocznymi śladami deskowań. W nawach bocznych umieszczono po trzy okrągłe, witrażowe okna. W transepcie i prezbiterium wstawiono okna arkadowe, o formie zbliżonej do biforium, znajdujące się w parach płytkich nisz przedzielonych półkolumną. Zarówno nawa główna jak i transept przekryte są wysokimi dachami dwuspadowymi, natomiast nawy boczne - pulpitowymi.

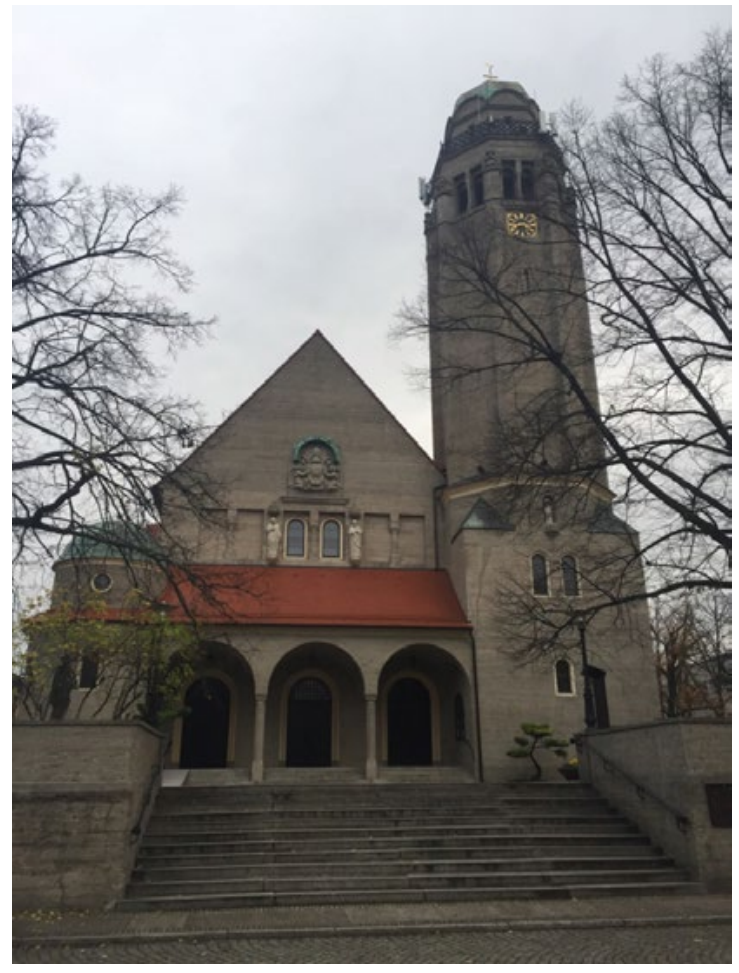

Ryc. 2. Widok kościoła od strony zachodniej.

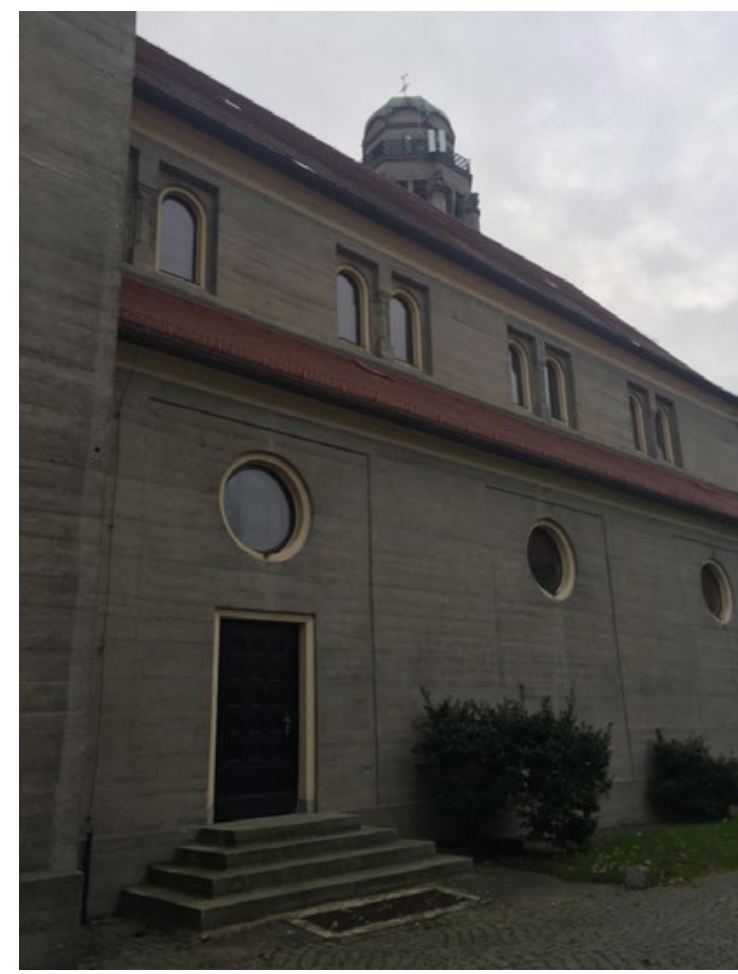

Ryc. 3. Fragment elewacji północnej z widocznymi śladami deskowań.

Sklepienia nawy głównej i naw bocznych są wykonane z drewna. Łuki arkad naw bocznych zdobione są geometrycznymi wzorami, natomiast łuk tęczowy okrągłymi portretami świętych. Ołtarz główny, w którym znajdują się relikwie świętych Klementyny i Diodory został wykonany przez Kurta Spribille, natomiast dwa ołtarze boczne zostały wykonane według projektu rzeźbiarza Georga Schreinera. Droga krzyżowa została namalowana przez Kaspra Schleibnera z Monachium. Ambonę obłożoną płytami marmurowymi z postaciami ewangelistów oraz chrzcielnicę z piaskowca wykonał Josef Knauer z Opola. Obiekt został konsekrowany 24 października 1924 roku [2]. Obok kościoła wybudowano plebanię, która nawiązuje do niego formą i użytymi materiałami. Jest również wykonana z betonu i przekryta dwuspadowym dachem. 


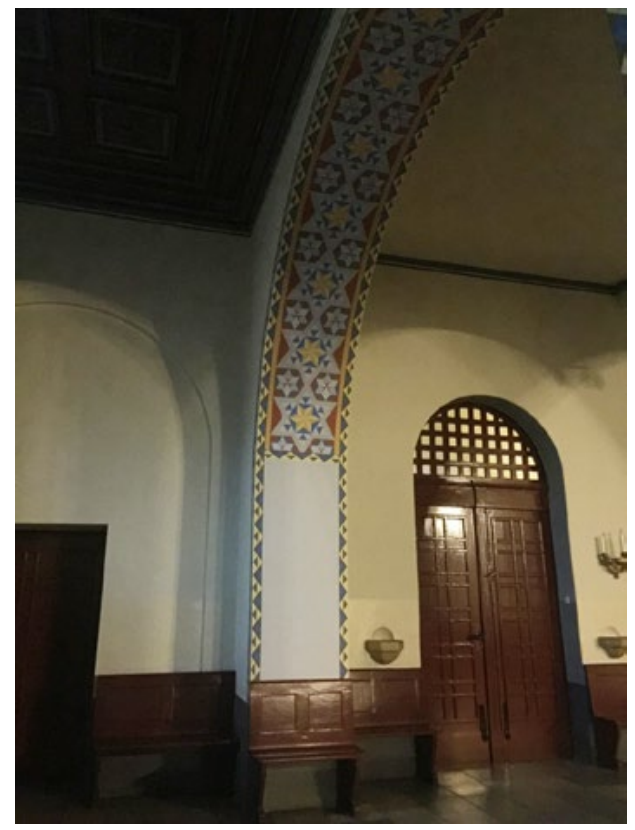

Ryc. 4. Fragment arkady nawy bocznej.

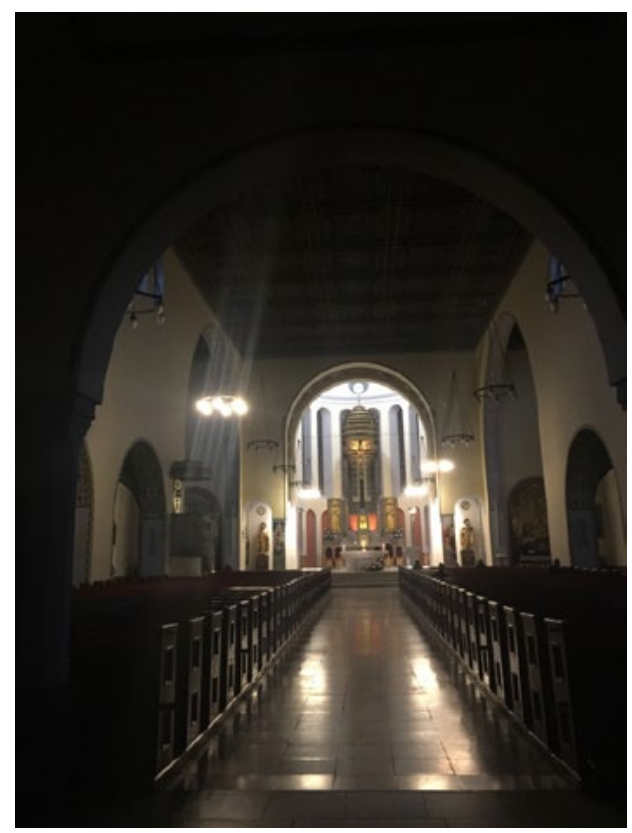

Ryc. 5. Wnętrze kościoła.

W projekcie zastosowano tradycyjne rozwiązania przestrzenne, jednak zastosowanie betonu miało zdecydowany wpływ na jego nowoczesną, zewnętrzną formę. Widoczny rysunek deskowań dodatkowo podkreśla jej surowość. Na uwagę zasługuje również prostota wnętrza, które, za wyjątkiem złoconych ołtarzy bocznych, zdobione jest dość oszczędnie. Do wykonania całości świątyni zastosowano lokalnie dostępne materiały takie jak cement, drewno, czy piaskowiec, z którego wykonano chrzcielnicę oraz kropielnice.

\section{Kościół Najświętszego Serca Pana Jezusa - 1930 r.}

Budowę kościoła pw. Najświętszego Serca Pana Jezusa rozpoczęto i zakończono w 1930 roku. Świątynia powstała obok wcześniej wzniesionego przez jezuitów domu zakonnego znajdującego się na gruncie pomiędzy ulicami Sedanstrasse (obecnie ul. Grunwaldzka) i Rosenbergerstrasse (obecnie ul. Oleska). Obiekt powstawał w otoczeniu nielicznej zabudowy mieszkaniowej [3]. Kościół jest trójnawowym, niezorientowanym obiektem w układzie bazylikowym rozmieszczonym na planie prostokąta, w dolnej części wykonany z piaskowca, a w górnej z cegły. Zakończone absydą prezbiterium znajduje się w południowej części budowli i połączone jest z budynkiem plebanii. Dobudowaną po II wojnie światowej kruchtę z trzema wejściami głównymi umieszczono na północnej stronie kościoła. Nawa główna wsparta jest przyporami w miejscu gdzie jeszcze w latach 30. XX wieku dokonano jej rozbudowy o trzy przęsła. Czworoboczna wieża umiejscowiona jest przy wschodnich murach kościoła na wysokości chóru kapłańskiego. W jej dolnej części znajduje się prostokątny otwór drzwiowy z wykutą na nadprożu łacińską sentencją „EGO SVM OSTIUM”, natomiast w jej górnej części cztery łukowe otwory okienne, znajdujące się w miejscu umieszczenia dzwonów. Wieża nakryta jest czterospadowym dachem zwieńczonym sygnaturką. Zarówno dach wieży, jak i dwuspadowy dach nawy głównej kryte są ceramiczną dachówką, natomiast pulpitowe dachy niższych naw bocznych kryte są blachą miedzianą. Części obiektu wykonane z cegły otynkowano. W bryle kościoła ulokowano otwory okienne o różnych kształtach: w części prezbiterialnej są prostokątne i kwadratowe, w nawie głównej łukowe, natomiast w nawach bocznych eliptyczne, a w ich przebudowanych częściach - prostokątne. Dodatkowo w dachu nawy głównej umieszczono lukarny z eliptycznymi otworami, dodatkowo doświetlającymi wnętrze. Przy wschodniej nawie bocznej ulokowano niewielką kruchtę, w której znajduje się jedno z wejść do kościoła, zamknięte łukiem koszowym z płaskorzeźbą przedstawiającą symbolicznie Jezusa i jego serce. Podobnie jak przy wejściu do wieży, na nadprożu również wykuto sentencję „VENITE AD ME OMNES". Elewacja północna obecny kształt uzyskała pod koniec lat 70. XX wieku. W oryginalnym 
założeniu składała się z dwóch fragmentów: zdobionej czterema pilastrami i dwoma eliptycznymi oknami części zakończonej neobarokowym zwieńczeniem rozpoczynającym się na wysokości krawędzi dachu nawy głównej oraz znajdującego się powyżej trójkątnego frontonu z pojedynczym owalnym oknem. Po dodaniu kruchty zmieniła się forma elewacji oraz została ona uwspółcześniona. Oblicowane piaskowcem boki fasady rozszerzono ku dołowi, a na jej osi, w miejscu ulokowania chóru, umieszczono schodkowy element pokryty blachą miedzianą. Wejście do kruchty zadaszono.

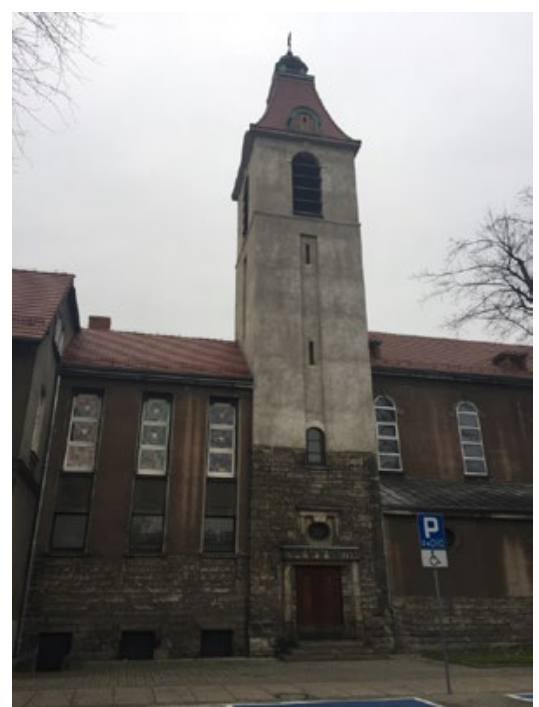

Ryc. 6. Wieża kościoła.

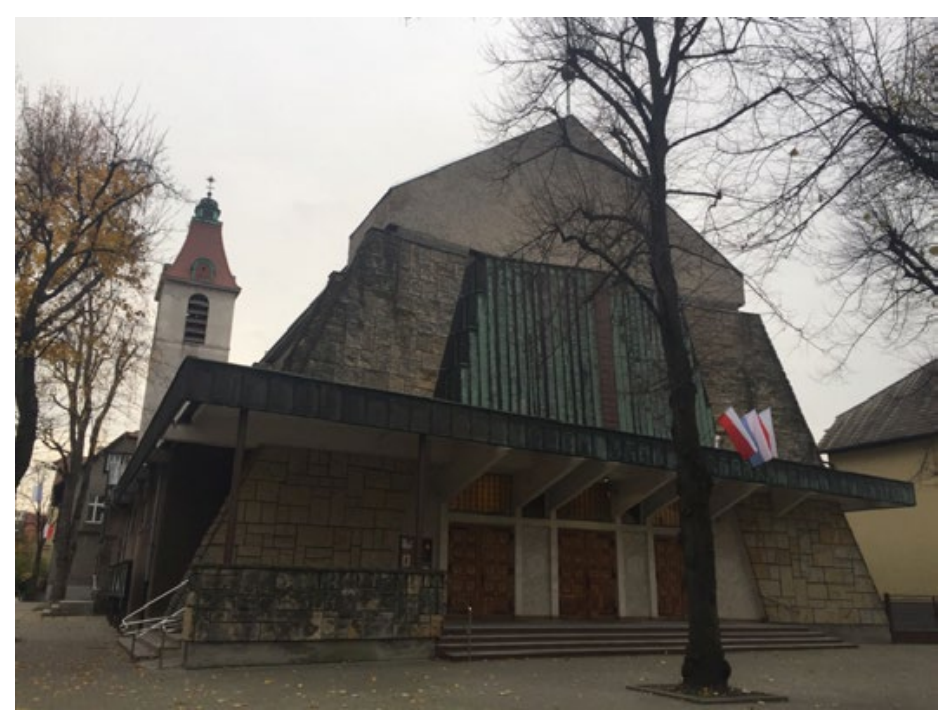

Ryc. 7. Przebudowana elewacja północna.

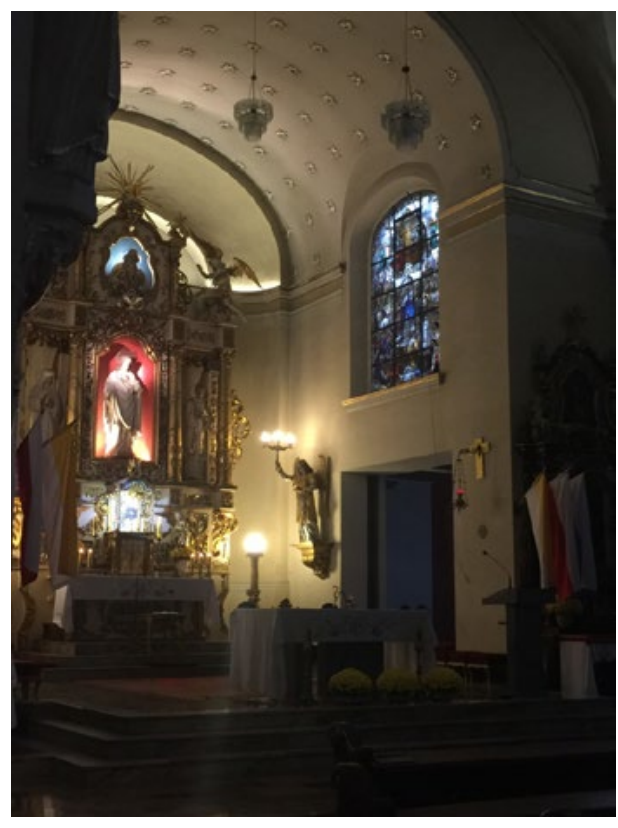

Ryc. 8. Widok wnętrza kościoła.

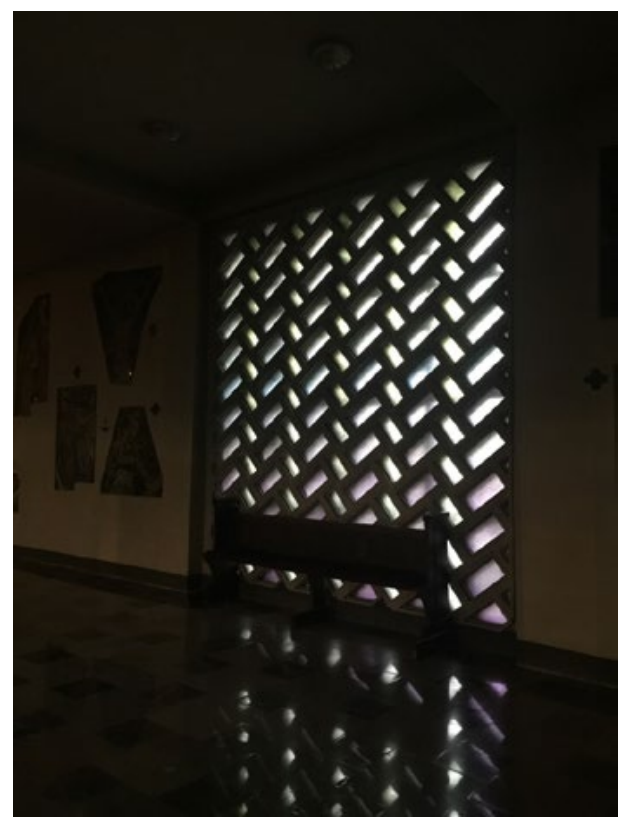

Ryc. 9. Współczesny detal architektoniczny.

Sklepienie nawy głównej jest sklepieniem kolebkowym z lunetami oraz gurtami, natomiast nawy boczne posiadają sufity. W arkadach naw bocznych znajdują się łuki koszowe. Filary nawy głównej są zdobione pilastrami, przy których ustawiono figury świętych. Oryginalnie wnętrze zostało pomalowane w tonacji białej i jasnożółtej 
[4], natomiast współcześnie dominują odcienie beżu i bieli a także umiarkowane złocenia. Ołtarze oraz ambona, znajdujące się w starszej części wykazują cechy neobarokowe, natomiast przebudowane fragmenty bryły zdobione są elementami o cechach współczesnych. Na uwagę zasługuje Droga Krzyżowa wykonana techniką mozaiki oraz witraże o wzorze przypominającym jodełkę.

Podczas budowy świątyni, podobnie jak w przypadku kościoła pw. Św. Piotra i Pawła, skorzystano z lokalnie występującego piaskowca. We wnętrzu widać przenikanie się stylów: znajduje się tu bardzo dużo neobarokowych elementów wyposażenia, wśród których pojawiają się detale współczesne. Choć są to różnice zauważalne, elementy te współgrają ze sobą dosyć dobrze.

\section{Kościół św. Józefa - 1928-1929}

Kolejną budowlą, która powstała w okresie międzywojennym, był kościół św. Józefa w Szczepanowicach - wsi, którą w 1936 roku administracyjnie włączono do granic Opola. Budowę świątyni rozpoczęto w 1928 roku przy Proskauerstrasse (obecnie ul. Prószkowska), według dokumentacji opracowanej przez nadradcę budowlanego Arthura Kicktona - głównego projektanta kościoła pw. św. Piotra i Pawła. Nadzór budowlany nad postępem prac, które ukończono w 1929 roku, sprawował radca budowlany Anton Mokros z Opola. Kościół ten jest trójnawową, odwrotnie orientowaną bazyliką z prezbiterium zakończonym wielokątną absydą. Wejście do znajdującej się od wschodu kruchty flankują dwie strzeliste wieże o formie ośmiokątnej. Wieże zdobione są zmieniającym się rytmem otworów okiennych, w jej dolnej części są to dwie pary zdwojonych, prostokątnych okien, natomiast w górnej trzy pojedyncze prostokątne okienka, występujące jedno nad drugim. Umieszczono je na co drugiej ścianie. W miejscu umieszczenia dzwonów ulokowano po osiem otworów - po jednym na każdej ze ścian. Ponad główną częścią każdej z wież umieszczono mniejszy, ośmioboczny tambur, w którym na osi otworów dzwonnicy, umieszczono osiem kwadratowych otworów okiennych. Jest on podstawą dla strzelistych hełmów wykonanych z blachy miedzianej. Konsekwentne stosowanie podobnego detalu jest widoczne również na elewacjach bocznych. W nawie głównej zastosowano rytm trzech prostokątnych okien, z których środkowe jest wyższe od skrajnych o 1/3 wysokości, natomiast nawach bocznych jedynym detalem są pary prostokątnych otworów. Elewacje otynkowano w 2016 i 2017 roku podczas prac remontowych. Nawa główna została przekryta wysokim, krytym dachówką ceramiczną, dwuspadowym dachem z lukarnami, natomiast nawy boczne przekryto dachami pulpitowymi z pokryciem z blachy. Główne drzwi otoczone są półkolistym portalem z kilkoma rzędami łuków cofającymi się wgłąb ściany. Po obu stronach głównego wejścia, w prostych, sklepionych łukowo niszach umieszczono dodatkowe drzwi.

Nad nawą główną znajduje się sklepienie sieciowe, natomiast nad prezbiterium sklepienie kryształowe. W ścianach wielobocznego prezbiterium znajdują się sporej wielkości okna witrażowe z wizerunkami świętych. Wystrój kościoła zmieniał się kilkukrotnie na przestrzeni dziesięcioleci, obecnie jest dużo skromniejszy niż przed laty. Z wnętrza prezbiterium zniknęła nastawa ołtarzowa w formie tryptyku, na jego ścianie powieszono natomiast sporej wielkości krucyfiks. Odmalowane w 2016 wnętrze świątyni zachowane jest w tonacji białej i jasnożółtej.

W projekcie tego kościoła widać podobne rozwiązania do tych zastosowanych w kościele pw. św. Piotra i Pawła. Oba wykonane są z betonu i są dość oszczędne w detalu, łączy je też osoba architekta - Arthura Kicktona. Świątynia poddawana jest stopniowemu remontowi, przez co powoli zatraca się oryginalny charakter elewacji i jej widoczna faktura. Sporym zmianom uległo również wyposażenie wnętrza oraz jego kolorystyka. 


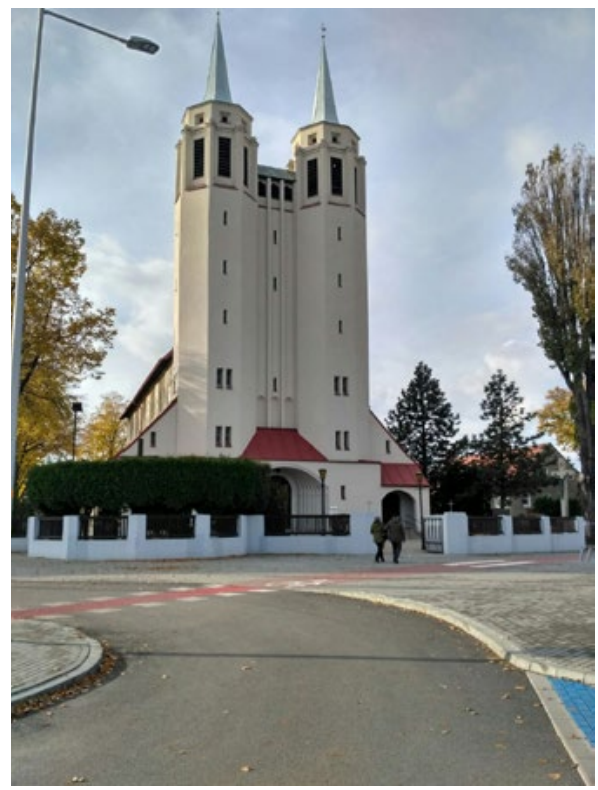

Ryc. 10. Elewacja wschodnia z dwoma wieżami.

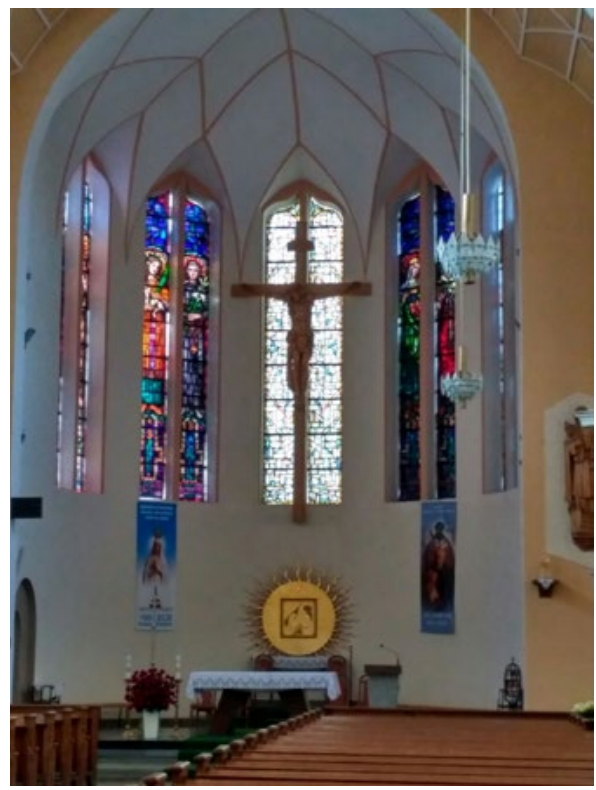

Ryc. 12. Wnętrze kościoła.

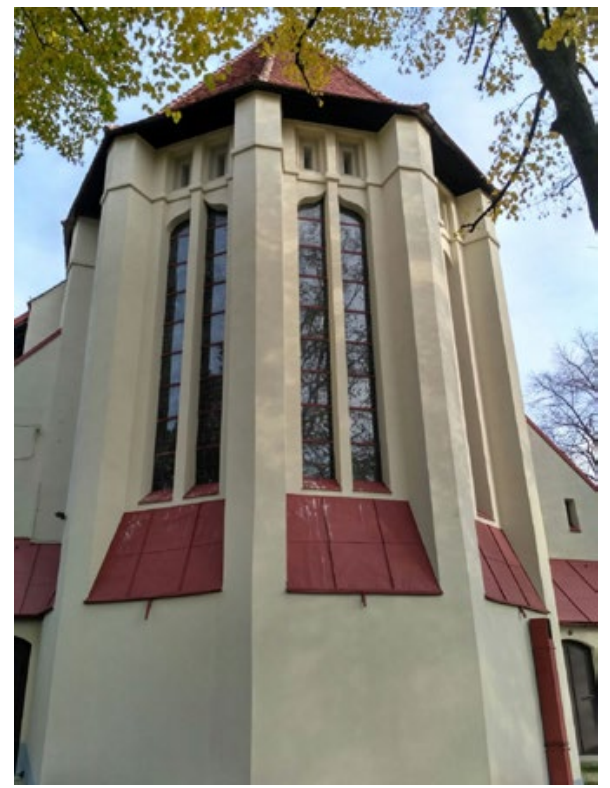

Ryc. 11. Prezbiterium.

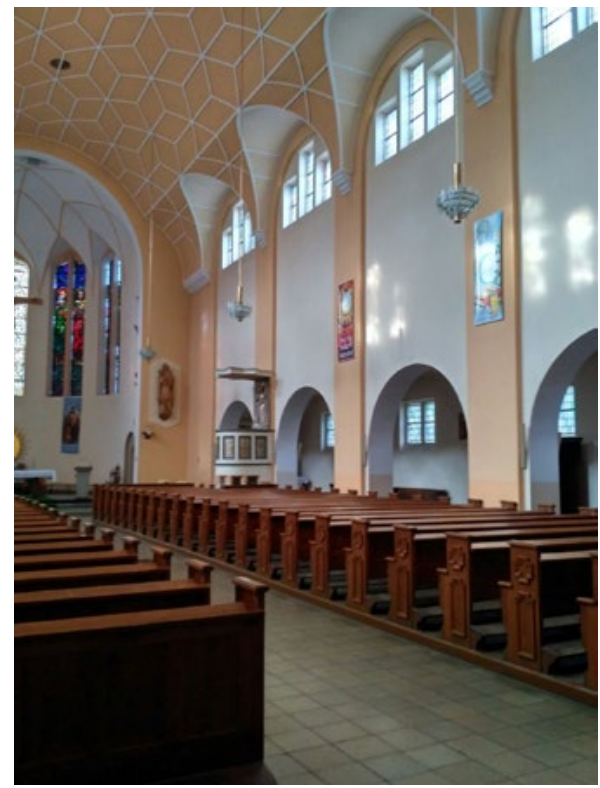

Ryc. 13. Widok na część ołtarzową.

\section{Kościół św. Michała Archanioła - 1936-1937}

Ostatnim kościołem, który powstał w latach 1918-1939 w granicach miasta jest kościół pw. św. Michała Archanioła w Opolu-Półwsi. Budowę rozpoczęto w 1936 roku według dokumentacji opracowanej przez Antona Mokrosa, a zakończono w 1937 roku. Świątynia jest trójnawową, nieorientowaną bazyliką z wieżą na planie prostokąta umieszczoną po stronie zachodniej. Umieszczono w niej troje drzwi, które prowadzą do wnętrza kościoła. Na ich osiach znajdują się trzy półokrągłe okna, a nieco wyżej pojedyncze okrągłe. W miejscu umieszczenia dzwonów 
znajdują się trzy łukowe okna, a ponad nimi niewielki balkon, do którego wejście obecnie jest zamurowane. Boki wieży flankowane są przybudówkami. Podobnie jak w przytoczonych wyżej rozwiązaniach detalem tworzącym elewacje boczne jest rytm okien. W nawie głównej są to osiowo rozmieszczone okna okrągłe, natomiast w nawach bocznych znajdują się otwory zakończone łukowo. W bocznych elewacjach wieży umieszczono po siedem otworów - dwa duże łukowe okna, a poniżej i powyżej nich po parze sporo mniejszych o takiej samej formie. Najmniejsze z nich zdobi natomiast szczyt ściany. Dachy nawy głównej i wieży są dwuspadowe, natomiast naw bocznych i przybudówek pulpitowe, wszystkie kryte dachówką ceramiczną. Obiekt został wzniesiony z cegły, a następnie otynkowany.

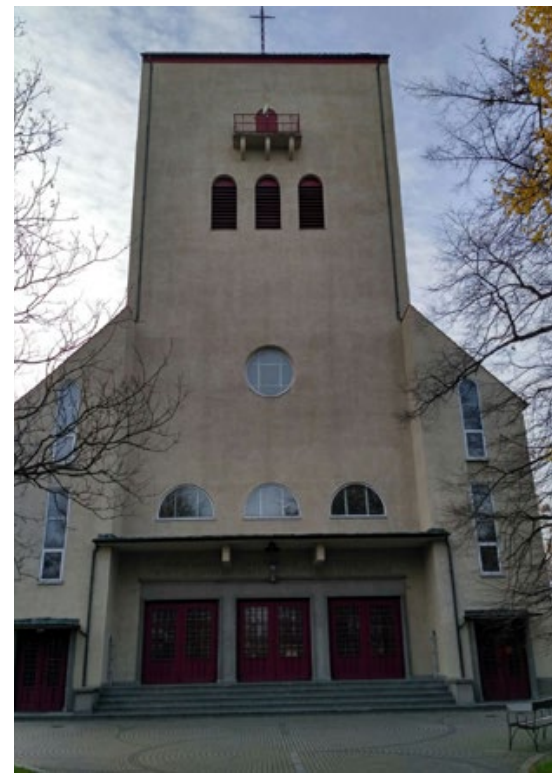

Ryc. 14. Elewacja zachodnia

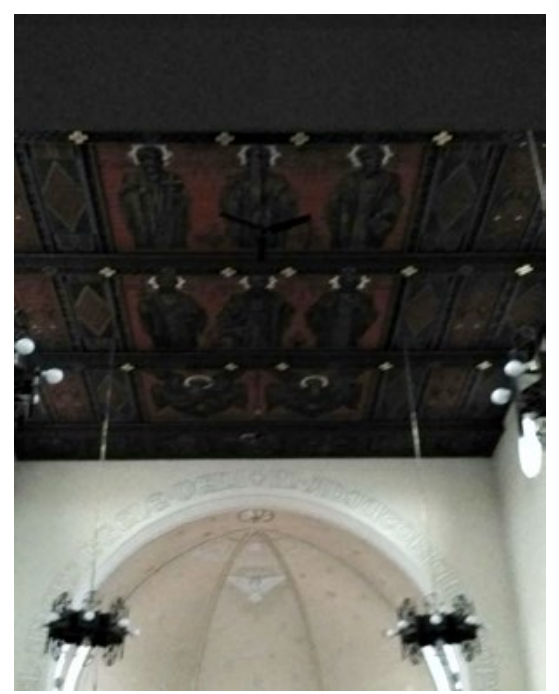

Ryc. 16. Drewniany sufit z wizerunkami apostołów

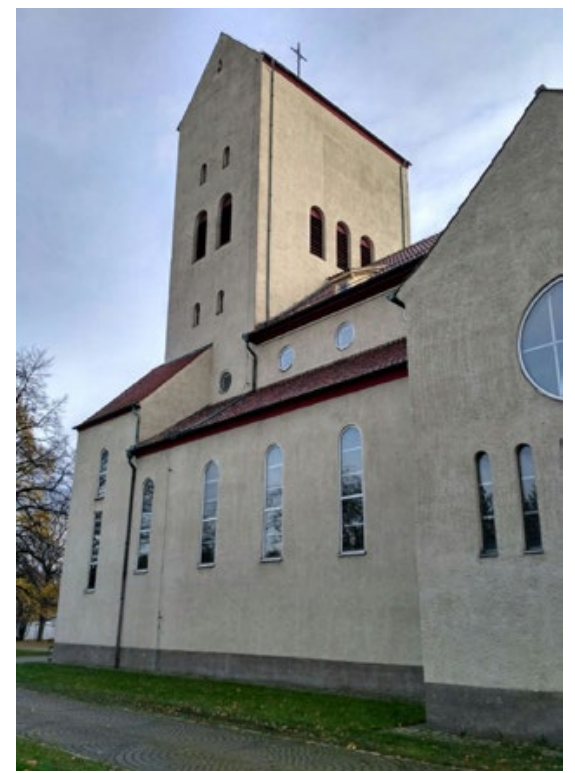

Ryc. 15. Fragment elewacji południowej

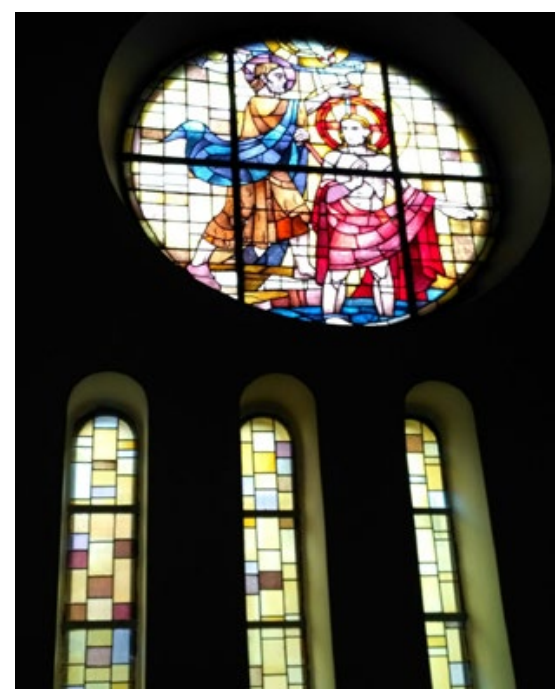

Ryc. 17. Okno witrażowe

Wnętrze kościoła zostało odmalowane i utrzymane jest w tonacji białej i jasnożółtej z niewielkim udziałem złoceń. Schodkowe prezbiterium zdobi wizerunek św. Michała Archanioła, namalowany na jednej ze ścian. 
Ołtarze boczne ozdabiają płaskorzeźby z wizerunkami świętych. Drewniany sufit ozdobiony jest postaciami apostołów. Część wyposażenia kościoła została zmieniona podczas remontu.

Kościół św. Michała Archanioła również czerpie ze wcześniejszych rozwiązań, które pojawiały się w wybudowanych nieco wcześniej opolskich świątyniach. Występuje tutaj sufit wykonany z drewna, podobnie jak w kościele św. Piotra i Pawła. Ze wszystkich powstałych w tamtym okresie kościołów jest najbardziej oddalony od centrum miasta.

Opolskie obiekty architektury sakralnej powstałe w dwudziestoleciu międzywojennym są świątyniami wielonawowymi o układzie bazylikowym. Podczas budowy starano się korzystać z lokalnie występujących materiałów, jakimi były cement, piaskowiec i drewno, co obniżało koszty ich wykonania. Jedynie najpóźniej zbudowany kościół św. Michała Archanioła został w całości wybudowany z cegły. Wszystkie kościoły cechuje oszczędne stosowanie detalu, elewacje kształtowano głównie poprzez grę otworów okiennych, które łączono ze sobą w różnych zestawieniach i rytmach. W każdym z kościołów znajduje się wieża, a w przypadku kościoła w Szczepanowicach nawet dwie, w których znajdują się dzwonnice. Są to również najbardziej zdobione części każdej ze świątyń. Opolskie kościoły łączą również te same osoby na stanowiskach projektantów i nadzorców. Dwie z nich, betonowe świątynie św. Piotra i Pawła oraz św. Józefa zostały zaprojektowane przez Arthura Kicktona. Dokumentację do najmłodszego kościoła św. Michała Archanioła opracował zaś Anton Mokros, który wcześniej nadzorował budowę kościoła w Szczepanowicach. Obecnie świątynie są stopniowo remontowane i oryginalny wystrój zastępowany jest nowoczesnymi odpowiednikami.

\section{Literatura:}

[1] P. P. MANIURKA. Zabytkowe kościoły Opola i Muzeum Diecezjalne [w:] Renowacje i Zabytki nr 3/2010, s. 4.

[2] Materiały ze zbiorów Archiwum w Opolu, jednostka aktowa: 45/1191/0/3/645, Bauten den Kath. Pffergemeinde Oppeln (Peter Paul Kirche), Krs. Oppeln

[3] M. E. ADAMSKA. Wybrane aspekty rozwoju przestrzennego Opola w latach 1816-1945, dysertacja doktorska, s. 132.

[4] Poświęcenie kościoła Serca Jezusowego w Opolu [w:] Nowiny codzienne, R. 20, nr 253 z dnia 30.10.1930, s. 3.

[5] O. SPISLA. 1996, Oppeln in den Stürmen der Zeit, Die Stiftung, Ratingen-Hösel.

Summary: Due to the dynamic growth of the population of the city, it was necessary to build new housing estates and associated public facilities. Up to the 20th century there were only five Catholic churches in Opole, which were unable to host the growing number of people. Accordingly there were built four churches in Opole during the interwar period. The following article presents spatial solutions of St. Peter and Paul, Sacred Heart of Jesus, St. Joseph and St. Archangel Michael churches.

Key words: Opole, churches, modernism, interwar period 